\title{
PENGARUH TEMPAT MINUM NIPPLE DAN PARALON TERHADAP AWAL PRODUKSI FASE GROWER AYAM PETELUR
}

\author{
Wahyu Kolifah \\ Mahasiswa Program Studi Ilmu Ternak Fakultas Peternakan \\ Universitas Islam Balitar \\ Jl. Majapahit No. 04 Kota Blitar
}

ABSTRACT

The research aimed to defermine the effect of nipple and paralon drinking place on start production of growing period laying hens. This research was in Wahyu farm during 2 month. The 300 laying hens and 13 week were used in the trial. The laying hens divided into 2 group using the t-test. The treatment whice are nipple and paralon drinking place. The parameter abserved feed intake, ADG (Average Daily Gain), HDP (Hen Day Production), egg weight, and FCR (Feed Convertion Ratio).

The result showed that nipple and paralon drinking place were significanty $(P<0.05)$ on feed intake, ADG (Average Daily Gain), HDP (Hen Day Production), egg weight, and FCR (Feed Convertion Ratio). It's suggested to do paralon drinking place on lower capacity farm.

\section{Keyword: Feed Intake, ADG, Hen Day Production, Egg Weight and FCR}

\section{PENDAHULUAN}

Seiring dengan perkembangan penduduk yang semakin pesat, permintaan produk hasil ternak berupa protein hewani juga semakin meningkat. Salah satu produk yang dihasilkan adalah telur. Ayam petelur adalah ayam yang dipelihara dengan tujuan untuk menghasilkan telur. Ayam petelur memiliki 3 fase dalam pemeliharaanya yaitu fase starter, grower dan layer. Faktor yang mempengaruhi tingkat produksi adalah gen dan lingkungan. Faktor lingkungan berpengaruh besar dalam tingkat produktivitas ayam petelur. Keberhasilan ayam petelur fase layer di pengaruhi oleh kualitas ayam petelur pada fase grower. Menurut Fadilah dan Fatkhuroji (2013) pada pemeliharaan fase grower yang terpenting adalah pencapaian bobot badan yang sesuai standart, sehat, tingkat keseragaman tinggi dan mengalami dewasa kelamin tepat pada waktunya.

Faktor yang mempengaruhi keberhasilan pada fase grower diantaranya adalah pakan dan air minum. Menurut Fadilah dan Fatkhuroji (2013) pada pemeliharaan fase grower yang terpenting adalah pencapaian bobot badan yang sesuai standart, sehat, tingkat keseragaman tinggi dan mengalami dewasa kelamin tepat pada waktunya. Air minum adalah kebutuhan yang sangat penting bagi semua mahkluk hidup termasuk ternak. Bentuk tempat air minum berpengaruh terhadap tingkat konsumsi air minum yang dikonsumsi oleh ayam petelur. Ada 2 macam bentuk tempat air minum, yaitu: nipple dan paralon. Konsumsi air minum pada ayam petelur sangat dipengaruhi oleh tingkat produksi, jumlah pakan yang dikonsumsi, kesehatan ayam, dan temperature lingkungan.

Air yang dipergunakan untuk kepentingan peternakan dan kesehatan hewan harus memenuhi persyaratan baku mutu air sesuai dengan peruntukannya (Undang-Undang Republik Indonesia Nomor 41 Tahun 2014 Tentang Peternakan Dan Kesehatan Hewan).

Menurut Risnajati (2011) Air minum yang diberikan pada ayam petelur harus cukup dan baik kualitasnya. Ketersediaan air minum salah satunnya dipengaruhi oleh bentuk tempat air 
minum yang dikonsumsi untuk ternak, sehingga mutu pada tempat air minum akan berbeda pada tingkat performa ayam petelur fase grower. Dalam kondisi seperti ini diperlukan air minum dalam jumlah yang cukup agar produksi dan pertumbuhan optimum tetap tercapai. Berdasarkan uraian diatas, maka penelitian ini bermaksut untuk mengetahui perbedaan penggunaan tempat minum nipple dan paralon terhadap awal produksi fase grower ayam petelur

\section{MATERI DAN METODE}

Materi yang digunakan adalah ayam petelur tipe medium starin Isa Brown berumur 13 minggu dengan populasi 300 ekor, ransum yang digunakan adalh self mix, kandang yang digunakan tipe open house berbentuk battery individual bertingkat tiga. Tiap petak kandang dilengkapi dengan tempat pakan dan minum. Populasi 300 ekor ayam petelur fase grower dengan strain Isa Brown di bagi menjadi 2 kelompok. Masing-masing kelompok berjumlah 150 ekor ayam dan tiap deret berisi 25 ekor dengan starin yang sama, kelompok 1 menggunakan tempat minum nipple dan kelompok 2 menggunakan tempat minum paralon.

Metode Penelitian akan menggunakan satuan ternak (ekor), metode percobaan dengan membandingkan 2 perlakuan. Pada tiap perlakuan berjumlah 150 ekor dengan replikasi 150. Sehingga terdapat 2 kandang berbeda sebagai unit percobaan. Perlakuan yang dilakukan adalah dengan melihat perbedaan penggunaan tampat minum nipple dan paralon terhadap awal produksi fase grower ayam petelur. Penelitian ini menggunakan Uji T ( $t$-test) dengan perlakuan sebagai berikut:

- P1 = Perlakuan pertama menggunakan tempat minum nipple.

- P2 = Perakuan kedua menggunakan tempat minum paralon.

\section{Variabel Pengamatan}

\section{Feed Convertion Ratio (FCR)}

$$
\text { Konversi pakan }=\frac{\text { Ransum dihabiskan untuk produksi telur }(\mathrm{kg})}{\text { Produksi telur yang diperoleh }(\mathrm{kg})}
$$

Hen Day Production (HDP)

$$
H D P \%=\frac{\text { Jumlah produksi telur per hari (butir) }}{\text { Jumlah ayam hidup hari itu (ekor) }} \times 100 \%
$$

\section{Berat Telur}

$$
\text { Egg Mass }=\frac{\text { Bobot telur }(\mathrm{kg})}{\text { Jumlah ayam }(\text { ekor })}
$$

Pertumbuhan Bobot Badan

$$
A D G=\frac{B B_{A w a l}-B B_{A k h i r}}{\text { Hari }}
$$

\section{Analisis Data}

\section{Analisis yang digunakan adalah Uji t-test.}

Data yang diperoleh dari penelitian ini dianalisis menggunakan metode percobaan uji $\mathrm{t}(t$-test). Penelitian bertujuan untuk membandingkan dua macam perlakuan yang berbeda 
(Sastrosupadi 1995). Pada prinsipnya berbeda atau tidaknya dua macam perlakuan tersebut dapat diketahui dari perbandingan $t_{\text {hitung }}$ dan $t_{\text {daftar }}$.

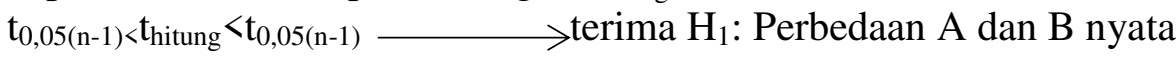

$\mathrm{t}_{\text {hitung }}>\mathrm{t}_{0,01(\mathrm{n}-1)} \longrightarrow$ terima H1: Perbedaan A dan B sangat nyata

$\mathrm{t}_{\text {hitung }}<\mathrm{t}_{0,05(\mathrm{n}-1)} \longrightarrow$ terima H0: Tidak ada perbedaan antara A dan B atau A dan B tidak nyata.

Penelitian ini menggunakan uji t ( $t$-test) tidak berpasangan (unpaired comparison) dengan asumsi ragam dua contoh sama, ulangan sama dengan populasi sama (Latipudin dan Mushawwir, 2011).

\section{HASIL DAN PEMBAHASAN}

\section{Konsumsi Pakan (Feed Intake)}

Tabel 1. Perbedaan konsumsi pakan (gram) minggu ke 13 sampai 21

\begin{tabular}{|c|c|c|c|c|c|c|}
\hline $\begin{array}{c}\text { Mgg } \\
\text { ke- }\end{array}$ & $\begin{array}{c}\text { Standart } \\
\text { Isa } \\
\text { Rrawn }\end{array}$ & $\begin{array}{c}\text { Nipple } \\
(\text { Rata-rata } \pm \text { SD })\end{array}$ & $\begin{array}{c}\text { Paralon } \\
(\text { Rata-rata } \pm \text { SD) }\end{array}$ & F 0.05 & F 0.01 & Ket \\
\hline 13 & 67 & $64.7 \pm 3.68$ & $66.7 \pm 2.80$ & $3.5>1.98$ & $3.5>2.61$ & $\mathrm{~N}$ \\
\hline 14 & 70 & $65.48 \pm 5.37$ & $66.9 \pm 4.95$ & $2.5>1.98$ & $2.5<2.61$ & $\mathrm{~N}$ \\
\hline 15 & 73 & $64.76 \pm 6.8$ & $68.22 \pm 6.38$ & $4.54>1.98$ & $4.54>2.61$ & $\mathrm{~N}$ \\
\hline 16 & 76 & $68.6 \pm 6.83$ & $71.44 \pm 6.34$ & $3.72>1.98$ & $3.72>2.61$ & $\mathrm{~N}$ \\
\hline 17 & 80 & $69.8 \pm 8.34$ & $71.93 \pm 8.84$ & $2.12>1.98$ & $2.12<2.61$ & $\mathrm{~N}$ \\
\hline 18 & 81 & $75.79 \pm 8.14$ & $76.24 \pm 8.4$ & $0.46<1.98$ & $0.46<2.61$ & $\mathrm{TN}$ \\
\hline 19 & 85 & $84.87 \pm 6.27$ & $85.77 \pm 6.17$ & $1.26<1.98$ & $1.26<2.61$ & $\mathrm{TN}$ \\
\hline 20 & 95 & $90.97 \pm 7.05$ & $92.51 \pm 5.28$ & $2.14>1.98$ & $2.14<2.61$ & $\mathrm{~N}$ \\
\hline 21 & 105 & $95.37 \pm 8.64$ & $97.32 \pm 6.31$ & $2.22>1.98$ & $2.22<2.61$ & $\mathrm{~N}$ \\
\hline
\end{tabular}

Sumber: Data primer 2017.

Rata-rata \pm SD konsumsi pakan yang dicapai pada perlakuan minggu ke 13, 14, 15, 16, 17, 20, 21 berpengaruh nyata $(\mathrm{P}<0.05)$ sedangkan terdapat perbedaan tidak nyata ( $>>0.05)$ pada minggu ke 18 dan 19 keberbedaan pada minggu ini dipengaruhi oleh suhu yang relative panas atau tinggi yaitu $33^{\circ} \mathrm{C}$ sehingga ayam petelur lebih banyak mengonsumsi air minum ketimbang pakan. Semua data menunjukkan perbedaan nyata $(\mathrm{P}<0.05)$ pada perlakuan paralon dan nipple dimana secara keseluruhan perlakuan paralon menghasilkan tingkat konsumsi pakan (feed intake) lebih besar dibandingkan dengan nipple. Hal ini menunjukkan bahwa model tempat minum berpengaruh nyata $(\mathrm{P}<0.05)$ terhadap konsumsi pakan (feed intake).

Dari hasil t-test dapat dijelaskan bahwa efisiensi penggunaan pakan lebih bagus menggunakan paralon dari pada penggunaan nipple. Dengan menggunakan tempat minum nipple konsumsi air yang dikonsumsi terhadap ayam petelur akan mengalami kekurangan terutama pada suhu yang tinggi, hal ini disebabkan karena ayam petelur mengalami keterbatasan dan tidak leluasa dalam mengonsumsi air minum. Signifikasi pada perlakuan paralon, paralon sesuai dengan kondisi fisiologi pada ternak yang akan berpengaruh pada produktivitas dan pertumbuhan.

Kurangnya konsumsi air minum pada ternak menyebabkan penurunan produktivitas dan pertumbuhan pada ayam petelur terutama pada fase grower (Risnajati, 2011). Berbeda dengan penggunaan paralon ayam petelur dapat minum secara leluasa tanpa harus mematuk dan pada suhu tinggi ayam akan mengalami panting (megap-megap) untuk mengeluarkan suhu panas dalam tubuh karena itu ayam petelur akan mengonsumsi air lebih banyak untuk mengurangi suhu panas dalam tubuh. Konsumsi air minum pada periode pertumbuhan adalah 
2 kali konsumsi ransum (Risnajati, 2011). Faktor dari perbedaan dua perlakuan nipple dan paralon adalah tingkat konsumsi air minum pada ayam petelur, kurangnya konsumsi air minum menyebabkan penurunan produktivitas dan pertumbuhan pada ayam petelur terutama pada fase pertumbuhan (Risnajati, 2011).

Perbandingan hasil penelitian dengan standart Isa Brown menunjukkan bahwa hasil penelitian selalu lebih rendah dibandingkan dengan standart Isa Brown. Fakta ini menunjukkan bahwa ayam petelur yang di pelihara di penelitian tidak mampu menunjukkan kapasitas genetik yang sesuai dengan tabel. Penyebab ketidak optimalan genetik ini di duga suhu pada tempat penelitian yang relative tinggi atau panas.

Hasil penelitian yang diperoleh selaras dengan teori yang menyatakan bahwa faktor yang dapat mempengaruhi konsumsi pakan (feed intake) adalah bobot tubuh ayam, jenis kelamin, aktivitas, suhu lingkungan, kualitas dan kuantitas pakan (Saepulmilah, 2010). Ayam petelur yang dipelihara di daerah iklim panas, kemungkinan untuk mencapai konsumsi pakan (feed intake) yang normal sangat sulit (Fadilah dan Fatkhuroji, 2013). Konsumsi pakan menurun $1.72 \%$ pada setiap kenaikan $1^{\circ} \mathrm{C}$ dari suhu ambang antara $18^{\circ} \mathrm{C}$ sampai $32^{\circ} \mathrm{C}$. Penurunan menjadi lebih cepat $\left(5 \%\right.$ untuk setiap $1^{\circ} \mathrm{C}$ ) apabila suhu meningkat ke $32-38^{0} \mathrm{C}$ (Rifqi, 2008).

Risnajati (2011) menyatakan bahwa konsumsi pakan (feed intake) pada penelitian ayam petelur fase grower adalah 67.5 gram, sedangkan hasil penelitian tingkat konsumsi pakan (feed intake) adalah 64.7-95.37 gram pada perlakuan nipple dan 66.7-97.32 gram pada perlakuan paralon. Hasil perbandingan dengan penelitian tidak berbeda jauh.

\section{ADG (Average Daily Gain)}

Tabel 2. ADG (Average Daily Gain) gram

\begin{tabular}{|c|c|c|c|c|c|}
\hline Perlakuan & Standart & Rata-rata \pm SD & F 0.05 & F 0.01 & Ket \\
\cline { 1 - 4 } Isa Brown & & & & \\
\cline { 1 - 5 } Nipple & 565 & $488.7 \pm 1.72$ & $64.7>1.98$ & $64.7>2.61$ & $\mathrm{~N}$ \\
\cline { 1 - 1 } & & $533.8 \pm 2.41$ & & & \\
\hline
\end{tabular}

Sumber: Data primer 2017

Rata-rata \pm SD ADG (Average Daily Gain) yang dicapai pada perlakuan nipple dan paralon berpengaruh nyata $(\mathrm{P}<0.05)$. Dari data ADG (Average Daily Gain) pada tabel 5 dapat dijelaskan bahwa terdapat keselarasan antara data konsumsi pakan (feed intake) dengan data ADG (Average Daily Gain). Hasil t-test menunjukkan bahwa terdapat perbedaan nyata $(\mathrm{P}<0.05)$ antara perlakuan nipple dengan perlakuan paralon. Pengaruh tingkat konsumsi pakan (feed intake) sangat berpengaruh dalam pertambahan bobot badan untuk memulai awal produksi pada ayam petelur, bobot badan yang sesuai standart menentukan dewasa tubuh pada ayam petelur yang kemudian diikuti dengan dewasa kelamin yang artinya ayam petelur sudah siap untuk berproduksi.

Perbandingan antara hasil penelitian dengan standart Isa Brown menunjukkan bahwa hasil penelitian lebih rendah dibandingkan dengan standart Isa Brown. Fakta ini menunjukkan bahwa ayam petelur yang di pelihara di penelitian tidak mampu menunjukkan kapasitas genetik yang sesuai dengan tabel. Penyebab ketidak optimalan genetik ini di duga suhu pada tempat penelitian yang relative panas. Hasil penelitian yang diperoleh selaras dengan hasil konsumsi pakan (feed intake) yang tidak sesuai dengan standart. 
Dari hasil t-test dapat dijelaskan bahwa efisiensi penggunaan pakan lebih bagus menggunakan paralon dari pada penggunaan nipple. Fungsi dari air sendiri adalah untuk membantu ayam petelur mencerna makanannya dalam tubuh, saat disediakan air menggunakan paralon ayam akan mudah untuk mengonsumsinya terlebih lagi pada suhu yang relative panas ayam tidak akan mengalami panting atau megap-megap untuk mengeluarkan suhu panas dalam tubuh karena sudah dibantu dengan kebutuhan air yang cukup. Sehingga konsumsi pakan (feed intake) lebih besar ketimbang penggunaan nipple. Risnajati (2011) menyatakan bahwa rata-rata pertambahan bobot badan pada penelitian ayam petelur fase grower adalah 512.00-530.33 gram, sedangkan hasil penelitian rata-rata pertambahan bobot badan ayam petelur fase grower adalah 488.7 gram pada perlakuan nipple dan 533.8 gram pada perlakuan paralon. Hasil perbandingan dengan penelitian tidak berbeda jauh.

\section{Hen Day Production (HDP)}

Tabel 3. Perbandingan HDP (\%) minggu ke 19 sampai 21.

\begin{tabular}{|c|c|c|c|c|c|c|}
\hline $\begin{array}{c}\text { Mgg } \\
\text { ke }\end{array}$ & $\begin{array}{c}\text { Standart } \\
\text { Isa } \\
\text { Brown }\end{array}$ & $\begin{array}{c}\text { Nipple } \\
(\text { Rata-rata } \pm \text { SD) }\end{array}$ & $\begin{array}{c}\text { Paralon } \\
(\text { Rata-rata } \pm \text { SD) }\end{array}$ & F 0.05 & F 0.01 & Ket \\
\hline 19 & 15 & $2.92 \pm 0.022$ & $3.01 \pm 0.024$ & $1.13<1.98$ & $1.13<2.61$ & TN \\
\hline 20 & 38 & $19 \pm 0.089$ & $20 \pm 0.12$ & $3.53>1.98$ & $3.53>2.61$ & $\mathrm{~N}$ \\
\hline 21 & 65 & $45 \pm 0.056$ & $53 \pm 0.052$ & $8.76>1.98$ & $8.76>2.61$ & $\mathrm{~N}$ \\
\hline
\end{tabular}

Sumber: Data primer 2017

Rata-rata \pm SD HDP (Hen Day Production) yang dicapai pada perlakuan minggu ke 20 dan 21 berpengaruh nyata $(\mathrm{P}<0.05)$ sedangkan terdapat perbedaan tidak nyata $(\mathrm{P}>0.05)$ pada minggu ke19 keberbedaan pada minggu ini dipengaruhi oleh konsumsi pakan (feed intake) pada minggu ke 19 tidak berbeda nyata $(\mathrm{P}>0.05)$. karena dipengaruhi suhu yang relative panas atau tinggi yaitu $33{ }^{\circ} \mathrm{C}$ sehingga ayam petelur lebih banyak mengonsumsi air minum ketimbang pakan.

Menurut Rahardjo (2012) pada cuaca panas, ayam akan minum lebih banyak sementara makannya berkurang. Dalam hal tersebut dalam penggunaan nipple ketika suhu panas tidak efisien terhadap konsumsi air minum pada ternak. Pada minggu pertama awal produksi tidak berbeda nyata $(\mathrm{P}>0.05)$ hal ini menunjukkan bahwa penggunaan tempat minum nipple dan paralon tidak berpengaruh terhadap HDP (Hen Day Production) pada awal bertelur.

Semua data menunjukkan perbedaan nyata $(\mathrm{P}<0.05)$ pada perlakuan paralon dan nipple dimana secara keseluruhan perlakuan paralon menghasilkan HDP (Hen Day Production) lebih tinggi dibandingkan dengan nipple. Hal ini menunjukkan bahwa model tempat minum berpengaruh nyata $(\mathrm{P}<0.05)$ terhadap HDP (Hen Day Production). Pada minggu ke 20 dan 21 perlakuan nipple dan paralon memperoleh hasil berbeda nyata $(\mathrm{P}<0.05)$ dari dua perlakuan tersebut dalam hal ini pada setiap minggu tingkat performa yang ditunjukkan terhadap penggunaan tempat minum paralon lebih baik dari pada nipple.

Perbandingan antara hasil penelitian dengan standart Isa Brown menunjukkan bahwa hasil penelitian selalu lebih rendah dibandingkan dengan standart Isa Brown. Hal ini menunjukkan bahwa ayam petelur Isa Brown tidak mampu menunjukkan performa pada status genetik atau standart, penyebab ketidak optimalan genetik ini di duga suhu pada tempat penelitian yang relative tinggi atau panas.

Bintang, Sinurat dan Purwadaria (2008) menyatakan HDP (Hen Day Production). pada penelitian ayam petelur strain Isa Brown umur 56 minggu adalah $84.42 \%$ data tersebut 
lebih rendah dengan standart Isa Brown, sedangkan hasil penelitian pada ayam petelur umur 19-21 minggu menunjukkan hasil HDP (Hen Day Production) adalah 2.92-45\% pada perlakuan nipple dan $3.01-53 \%$ pada perlakuan paralon. Hasil perbandingan dengan penelitian tidak berbeda jauh.

\section{Bobot Telur}

Tabel 4. Perbandingan bobot telur (gram) minggu ke 19 sampai 21

\begin{tabular}{|c|c|c|c|c|c|c|}
\hline $\begin{array}{c}\text { Mgg } \\
\text { ke- }\end{array}$ & $\begin{array}{c}\text { Standart } \\
\text { Isa } \\
\text { Brown }\end{array}$ & $\begin{array}{c}\text { Nipple } \\
(\text { Rata-rata } \pm \text { SD) }\end{array}$ & $\begin{array}{c}\text { Paralon } \\
(\text { Rata-rata } \pm \text { SD) }\end{array}$ & F0.05 & F0.01 & Ket \\
\hline 19 & 45 & $42.7 \pm 3.0$ & $44.2 \pm 3.22$ & $5.09>1.98$ & $5.09>2.6$ & $\mathrm{~N}$ \\
\hline 20 & 49 & $47.14 \pm 3.0$ & $46.8 \pm 2.15$ & $0.43<1.98$ & $0.43<2.6$ & TN \\
\hline 21 & 52 & $46.9 \pm 2.21$ & $51.3 \pm 2.17$ & $2.04>1.98$ & $2.04<2.6$ & $\mathrm{~N}$ \\
\hline
\end{tabular}

Sumber: Data primer 2017

Rata-rata \pm SD hasil t-test menunjukkan bahwa pada minggu ke 19 dan 21 bobot telur pada penggunaan nipple dan paralon berbeda nyata $(\mathrm{P}<0.05)$ sedangkan pada minggu ke 20 hasilnya tidak berbeda nyata $(\mathrm{P}>0.05)$. Hal ini dapat di jelaskan bahwa pada konsumsi pakan (feed intake) pada minggu ke 19 tidak berbeda nyata $(\mathrm{P}>0.05)$ karena dipengaruhi oleh suhu yang relative tinggi, berdampak pada bobot telur terlihat pada minggu ke 20, sehingga hasilnya pun tidak berbeda nyata $(\mathrm{P}>0.05)$ meskipun demikian HDP (Hen Day Production) pada awal bertelur minggu ke 19 tidak berbeda nyata $(\mathrm{P}>0.05)$. Dari hasil penelitian memperlihatkan bahwa penggunaan tempat minum nipple dan paralon dari tingkat efisiensi pakan dalam menghasilkan telur lebih bagus menggunakan tempat minum paralon untuk menghasilkan bobot telur yang bagus.

Perbandingan antara hasil penelitian dengan standart Isa Brown menunjukkan bahwa hasil penelitian selalu lebih rendah dibandingkan dengan standart Isa Brown. Fakta ini menunjukkan bahwa ayam petelur yang di pelihara di penelitian tidak mampu menunjukkan kapasitas genetik yang sesuai dengan tabel. Penyebab ketidak optimalan genetik ini di duga suhu pada tempat penelitian yang relative panas. Standart rata-rata berat telur ayam petelur dengan strain Isa Brown umur 19-21 minggu yaitu 45-52 gram sedangkan pada penelitian 42.7-46.9 gram pada nipple dan 44.2-51.3 gram pada perlakuan paralon (Isa Brown Management Guide, A Hendrix Genetics Company (2014).

Hasil penelitian yang diperoleh selaras dengan teori yang menyatakan bahwa faktor makanan terpenting yang diketahui mempengaruhi besar telur adalah protein dan asam amino yang cukup dalam pakan. Selanjutnya dijelaskan bahwa di samping ransum yang berkualitas air minum juga turut berpengaruh terhadap ukuran besar telur, dimana pada ayam yang kekurangan air minum akan mempengaruhi organ reproduksinya. Air merupakan senyawa penting dalam kehidupan.

Dua per tiga bagian tubuh hewan terdiri dari air dengan berbagai peranan untuk kelangsungan hidup (Sudaryani dan Santoso, 2008). Berat telur secara garis besar dipengaruhi oleh faktor termasuk genetik, namun faktor lingkungan juga berpengaruh dalam menentukan besar kecilnya telur seperti bangsa ayam, umur pertama bertelur, suhu lingkungan, tingkat protein dalam pakan dan bobot badan. Banyak faktor penyebab tidak tercapainya bobot telur sesuai standart salah satunya dipengaruhi oleh faktor lingkungan yang kurang baik. Dari suhu lingkungan peternakan di Desa Sumberasri Kecamatan Nglegok Kabupaten Blitar relative tinggi yaitu mencapai suhu $34^{\circ} \mathrm{C}$ sedangkan suhu nyaman bagi ayam petelur yaitu $25-23{ }^{\circ} \mathrm{C}$. Suhu dan kelembapan sangat menentukan proses berlangsungnya produktivitas. Suhu dan kelembapan yang nyaman bagi ternak akan meningkatkan 
produktivitas yang optimal. Saat suhu tinggi konsumsi pakan (feed intake) yang dikonsumsi ayam petelur menjadi berkurang dan ayam petelur lebih banyak untuk mengonsumsi air minum untuk mengurangi suhu panas dalam tubuh.

Tabel 5. Suhu dan kelembapan udara yang nyaman bagi ayam petelur

\begin{tabular}{|c|c|c|}
\hline $\begin{array}{c}\text { Umur } \\
\text { (hari) }\end{array}$ & $\begin{array}{c}\text { Suhu } \\
\left({ }^{\circ} \mathrm{C}\right)\end{array}$ & $\begin{array}{c}\text { Kelembapan } \\
(\%)\end{array}$ \\
\hline $0-3$ & $33-31$ & $55-60$ \\
\hline $4-7$ & $32-31$ & $55-60$ \\
\hline $8-14$ & $30-28$ & $55-60$ \\
\hline $15-21$ & $28-26$ & $55-60$ \\
\hline $22-24$ & $25-23$ & $55-65$ \\
\hline$>25$ & $25-23$ & $55-65$ \\
\hline
\end{tabular}

Sumber: Rass Manual Management, 2009 dan ISA Brown Manual Management 2009.

Budiarto dkk (2008) menyatakan bahwa bobot telur pada penelitian ayam petelur fase grower adalah 67.5 gram, sedangkan hasil penelitian tingkat konsumsi pakan (feed intake) adalah 64.7-95.37 gram pada perlakuan nipple dan 66.7-97.32 gram pada perlakuan paralon. Hasil perbandingan dengan penelitian tidak berbeda jauh.

\section{Feed Convertion Ratio (FCR)}

Tabel 6. Perbandingan Feed Convertion Ratio (gram) minggu ke 19 sampai 21

\begin{tabular}{|c|c|c|c|c|c|c|}
\hline $\begin{array}{c}\text { Mgg } \\
\text { ke- }\end{array}$ & $\begin{array}{c}\text { Standart } \\
\text { Isa } \\
\text { Brown }\end{array}$ & $\begin{array}{c}\text { Niplle } \\
(\text { Rata-rata } \pm \text { SD) }\end{array}$ & $\begin{array}{c}\text { Paralon } \\
(\text { Rata-rata } \pm \text { SD })\end{array}$ & F0.05 & F0.01 & Ket \\
\hline 19 & 1.86 & $2.05 \pm 0.18$ & $1.99 \pm 0.17$ & $1.98>1.98$ & $1.98<2.61$ & $\mathrm{~N}$ \\
\hline 20 & 1.93 & $2.03 \pm 0.19$ & $2.00 \pm 0.20$ & $2.02>1.98$ & $2.02<2.61$ & $\mathrm{~N}$ \\
\hline 21 & 2.01 & $1.89 \pm 0.17$ & $2.01 \pm 0.23$ & $6.85>1.98$ & $6.85>2.61$ & $\mathrm{~N}$ \\
\hline
\end{tabular}

Sumber: Data primer 2017

Rata-rata \pm SD FCR yang dicapai pada perlakuan minggu ke 19, 20, 21 berpengaruh nyata $(\mathrm{P}<0.05)$. Hasil uji t-test menunjukkan bahwa FCR pada perlakuan nipple dan paralon berpengaruh nyata. Menurut Rasyaf (2011) semakin kecil nilai FCR yang dimiliki ayam petelur semakin bagus nilai FCR ayam petelur tersebut. Dengan penggunaan tempat minum paralon mempermudah ayam untuk mengonkonsumsi air minum dibandingkan dengan penggunaan nipple, sehingga konsumsi air minum pada pemeliharaan ayam telur terpenuhi. konversi juga banyak dipengaruhi oleh teknik pemberian pakan (Rifqi, 2008). Konversi ransum didefinisikan sebagai berapa jumlah kilogram pakan yang dibutuhkan untuk menghasilkan satu kilogram produksi telur. Idealnya satu kilogram pakan dapat menghasilkan produksi telur $1 \mathrm{~kg}$ atau bahkan lebih.

Dinyatakan juga bahwa dengan bertambahnya umur ayam, maka konversi ransum semakin meningkat (Saepulmilah, 2010). Semakin tinggi konversi ransum menunjukkan semakin banyak ransum yang dibutuhkan untuk meningkatkan kualitas telur per satuan berat dan semakin rendah angka konversi ransum berarti kualitas ransum semakin baik. Konversi ransum ini berguna untuk mengukur produktivitas ternak (Saepulmilah, 2010). Konversi ransum yang baik berkisar 1,75-2,00.

Lokapimasari, Setyono dan Lamid (2012) menyatakan bahwa konversi pakan pada penelitian ayam petelur adalah 2.21-2.10 gram, sedangkan hasil penelitian menunjukkan 
tingkat konversi pakan adalah 2.05-1.89 pada perlakuan nipple dan 1.99-2.01 pada perlakuan. Hal ini dapat dijelaskan bahwa hasil perbandingan dengan penelitian menunjukkan hasil yang berbeda, yaitu hasil penelitian lebih rendah dalam konversi pakan dari pada peneliti terdahulu.

\section{KESIMPULAN DAN SARAN}

\section{Kesimpulan}

Pengaruh tempat minum nipple dan paralon terhadap awal produksi fase grower ayam petelur berpengaruh nyata $(\mathrm{P}<0.05)$ penggunaan tempat minum paralon lebih baik dari pada penggunaan nipple seperti yang terlihat pada konsumsi pakan (feed intake), ADG (Average Daily Gain), HDP (Hen Day Production), bobot telur yang lebih besar dari nipple dan FCR yang lebih kecil.

\section{Saran}

Untuk mempertahankan produktivitas pada ayam petelur, para peternak harus mempertimbangkan kebutuhan air minum pada ayam petelur. Karena dalam hal ini kebutuhan air minum sangat mempengaruhi tingkat produktivitas ayam petelur. Dalam hal ini penggunaan tempat minum paralon memudahkan ayam petelur untuk mengonsumsi air minum dengan baik. Sehingga kebutuhan air minum sangat terpenuhi. Dalam hal ini dapat dilihat dari feed intake kemudian akan berpengaruh terhadap HDP, bobot telur, maupun FCR penggunaan tempat minum paralon lebih bagus dibandingkan dengan penggunaan tempat minum nipple yang sangat terbatas.

Namun dalam hal ini perlu di perhatikan jumlah populasi yang dipelihara, apabila dalam jumlah populasi sedikit penggunaan paralon sangat bagus, namun dalam jumlah populasi yang besar penggunaan tempat minum paralon tidak efisien dalam ketenagakerjaan.

\section{DAFTAR PUSTAKA}

Budiarto, Dhamayanti. Y, Arimbi.2008. Peningkatan Tebal Cangkang Dan Berat Telur Layer dengan Pakan Rendah Protein yang Disubtitusicrude Chlorella. Veterinary Anatomy Journal. Vol. 1. No. 2. Fakultas Kedokteran Hewan Unair. Surabaya

Fadilah.R dan Fatkhulroji. 2013. Memaksimalkan Produksi Ayam Ras Petelur.. Agromedia. Jakarta.

Isa Brown. 2009. Isa Brown Commercial Management Guide. (http://www. isapoultry.

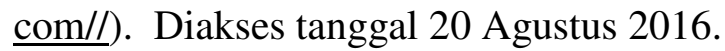

Isa Brown. 2014. Isa Brown Commercial Management Guide. (http://www. isapoultry.

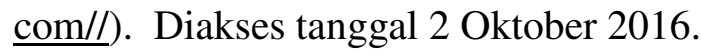

Khumaini.A. Mudawaroch.E.R. A.D.Hanung. 2012. Pengaruh Penambahan Sari Kunyit (Curcuma domestica Val) Dalam Air Minum Terhadap Konsumsi Pakan dan Konsumsi Air Minum Ayam Broiler. Surya Agritama. Vol. 1. No. 2. Universitas Muhammadiyah Purworejo. 
Lokapirnasari. W. P, Setyono. H, Lamid. M. 2012. Konversi Dan Konsumsi Pakan dari Formulasi Pakan dengan Kandungan Protein Berbeda. Veterinaria Medika Vol. 5. No. 1. Fakultas Kedokteran Hewan Unair. Surabaya

Mampioper Alberth dan Pattiselanno Freddy. 2008. Kualitas Telur Ayam Petelur Yang Mendapatkan Ransum Perlakuan Subtitusi Jagung Dengan Tepung Singkong. Jurnal Ternak Tropika. Vol. 9. No. 2. Program Studi Produksi Ternak FPPK UNIPA.

Mushawwir A, Latipudin D. 2011. Beberapa Parameter Biokimia Darah Yam Ras Petelur Fase Grower Dan Layer dalam Lingkungan"Upper Zonathermoneutural". Jurnal Peternakan Indonesia Vol. 13 No. 3. ISSN 1907-1760. Bandung

Risnajati Dede.2011. Pengaruh Pengaturan Waktu Pemberian Air Minum yang Berbeda Temperatur terhadap Performa Ayam Petelur Periode Grower.Sains Peternakan Vol.9 No. 2. ISSN 1693-8828. Bandung

Sarwanto. D dan Hendra. E. 2011. Analisis Kualitas Air Minum Sapi Perah Rakyat di Kabupaten Banyumas Jawa Tengah. Media Peternakan. Vol. 13

No.1. Universitas Wijayakusuma Purwokerto dan Universitas Jendral Soedirman Purwokerto. Jawa Tengah

Sastrosupadi Adji. 1995. Rancangan Percobaan Praktis Untuk Bidang Pertanian. Penerbit Kanisius. Yogyakarta

Undang-Undang Republik Indonesia Nomor 41 Tahun 2014 Tentang Peternakan Dan Kesehatan Hewan. 